\title{
Screening of cytotoxic activities toward WiDr and Vero cell lines of ethyl acetate extracts of fungi-derived from the marine sponge Acanthostrongylophora ingens
}

\author{
Ibtisamatul Aminah $^{1}$, Andani Eka Putra ${ }^{2}$, Dayar Arbain ${ }^{1}$, Dian Handayani ${ }^{1 *}$ \\ ${ }^{1}$ Sumatran Biota Laboratory, Faculty of Pharmacy, University of Andalas, Padang, Indonesia. \\ ${ }^{2}$ Faculty of Medicine, Andalas University, Padang, Indonesia.
}

\section{ARTICLE INFO \\ Received on: 14/10/2017 \\ Accepted on: 11/09/2018 \\ Available online: 31/01/2019}

Key words:

Acanthostrongylphora ingens, Aspergillus ochraceus, cytotoxic activity, marine sponge derived fungi, molecular identification.

\begin{abstract}
Ethyl acetate extracts of fungi-derived from the marine sponge Acanthostrongylophora ingens were tested for cytotoxic activity against WiDr and Vero cell lines. Three of fungi extracts exhibited strong cytotoxicity with percentage of viability $(\leq 50 \%)$ occurring at concentrations of $100 \mu \mathrm{g} / \mathrm{ml}$. One isolate (IB141) showed specific cytotoxicity against WiDr cells whreas not against Vero cells. This isolate was identified based on molecular characterization using sequence analysis of the partial $18 \mathrm{~S}$ rRNA gene. The result indicated that IB141 was identical to Aspergillus ochraceus. A comparatively high part of positive bio-activity screening results were acquired in this study, displaying that the fungi-derived from the marine sponge $A$. ingens have potential as a source of new anti-cancer agents.
\end{abstract}

\section{INTRODUCTION}

Marine-derived microbial communities have been focused more in the recent research. The species composition is diverse and shows temporal and geographical variations (Webster et al., 2001; Brigitte, 1980). The bacteria and fungi in these communities are the potential source of a wide range of bioactive natural products (Rateb and Ebel, 2011; Subramani et al., 2013; Thomas et al., 2010). Marine sponges have repeatedly been shown to contain previously unknown bioactive strains of fungal species (Pitt, 2000; Sun et al., 2012; Wiese et al., 2011). It should be noted that the same fungal species from a different sponge species produced dissimilar secondary metabolites (Jadulco et al., 2002). These sponges are the single most productive source of marine

"Corresponding Author

Dian Handayani, Faculty of Pharmacy, Andalas University, Padang, Indonesia.E-mail: dianhandayani@phar.unand.ac.id fungi that producing large numbers of bioactive compounds and secondary metabolites found to date (Bugni and Ireland, 2004; Bhadury et al., 2006; Proksch et al., 2003). In addition, many of these secondary metabolites are novel compounds with anticancer, anti-inflammatory, anti-microbial, or anti-viral properties (Elsebai et al., 2011; Lee et al., 2013; Li et al., 2013).

Cancer is a frightening human disease, increased along by changes in lifestyle, nutrition, and environmental conditions (Jemal et al., 2011; Marmot et al., 2007; Veer and Kampman, 2007). The treatment of cancer does not hold an effective medicine because the currently available drugs are producing severe side effects. The advances in the knowledge of cancer biology have made it possible to expand strategies in finding new anti-cancer drugs. It is of interest to record that further than $50 \%$ of the drugs applied in the therapy of cancer come from nature (Boopathy and Kathiresan, 2010). The natural products derived from the ocean are a significant source to discover new anti-cancer agents, including marine-derived fungi. Fungi derived from marine to prove become a kind candidate as a resource of new anti-cancer 
compounds. For continuing our work on bioactive secondary metabolites produced by fungi-derived from mangrove plants and marine sponges (Handayani and Artasasta, 2017; Handayani et al., 2016; 2017; 2018), a preliminary study on the anti-bacterial and cytotoxic activities of ethyl acetate extracts of fungi-derived from the marine sponge Acanthostrongylophora ingens has been conducted (Handayani and Aminah, 2017). This provided study is a continuity of the attempt to find out the cytotoxic activity of ethyl acetate fungi extracts against a WiDr cancer cell line and Vero normal cells.

\section{MATERIALS AND METHODS}

\section{Sponge material}

Acanthostrongylphora ingens is taken from the sea around Mandeh Island, West Sumatra, from a depth of $\pm 5-8 \mathrm{~m}$. It was transferred to a sterilized plastic bag and borned in an ice box for transfer to the laboratory. Taxonomic identification of this sponge has been identified by Dr. Nicole J. De Voogd, at the Natural Biodiversity Center, Netherlands. A voucher specimen, named IB101, has been conserved in the Marine Reference Collection, the Biota Sumatra Laboratory, Andalas University, West Sumatra, Indonesia.

\section{Isolation and cultivation of fungi-derived from sponge}

The sterilized sponge surface by rinsing with sterile seawater was cut into small pieces. Ten grams were entered into an Erlenmeyer flask with $100 \mathrm{ml}$ of sterilized seawater then more seawater was added to produce a 10-6 dilution. The resulting mixture was used to inoculate sabouraud dextrose agar and incubated at $27^{\circ} \mathrm{C}-29^{\circ} \mathrm{C}$ for $5-7$ days. Colonies were differentiated by shape and color and purified by pouring method to get pure isolates. The pure isolates were carried out based on Brigitte methods (1980). The pure isolates of fungi derived from the sponge were cultivated in a rice medium and then incubated for 4-6 weeks at room temperature until the medium was covered with the fungi (Kjer et al., 2010).

\section{Extraction of secondary metabolites from fungi isolates}

Ethyl acetate was then extracted from each of these fungal isolates with ethyl acetate (EtOAc). The EtOAc extracts were collected and evaporated in vacuo using a rotary evaporator then tested for cytotoxic activity using an MTT (3-[4,5-dimethylthiazol2-yl]-2,5 diphenyl tetrazolium bromide) assay against WiDr and Vero cell lines.

\section{Cytotoxic screening}

Cell line

WiDr cancer cells and Vero normal cells were obtained from CCRC, Faculty of Pharmacy, Gadjah Mada University. These cells were preserved in RPMI-1640 amplifier with $10 \%$ FBS (Fetal bovine serum), penicillin $(10,000 \mathrm{U} / \mathrm{ml})$, streptomycin $(10 \mathrm{mg} / \mathrm{ml})$, and fungizone $(0.5 \mathrm{ml})$ in a moistened atmosphere of $50 \mu \mathrm{g} / \mathrm{ml} \mathrm{CO}_{2}$ at $37^{\circ} \mathrm{C}$.

MTT assay

The cytotoxicity of the ethyl acetate extracts of fungi against WiDr cancer cells was tested by MTT assay. In 96-well plates, $5 \times 10^{3} /$ well of cells were gilded in $100 \mu \mathrm{l}$ of medium/well.
Then it was incubated overnight in a moistened atmosphere with $5 \% \mathrm{CO}_{2}$ at $37^{\circ} \mathrm{C}$ and the extracts with concentration of $100 \mathrm{ppm}$ were added. After addition of the extracts, $100 \mu \mathrm{l}$ of $0.5 \mathrm{mg} / \mathrm{ml}$ MTT ( $\mathrm{pH} 4.7$ ) per well and the plates cultured for 4 hours. The reaction ended with $100 \mu \mathrm{LDS} 10 \%$ in $0.01 \mathrm{~N} \mathrm{HCl}$ per well and incubated overnight. The absorbance at $595 \mathrm{~nm}$ was measured using an ELISA (Enzyme-Linked Immunosorbent Assay) reader (Bio-Rad). Doxorubicin was formed as a positive control. All trials were done in triplicate (Permanasari et al., 2016). The results of fungal extract on the growth of WiDr cancer cells were avowed as a percentage of viability was given as follows:

$$
\begin{gathered}
\% \text { Cell viability then calculated } \\
\text { by the equation }
\end{gathered}=\frac{\text { OD of treatmnet-OD of blank }}{\text { OD of control-OD of blank }} \times 100 \%
$$

\section{Molecular identification}

\section{DNA extraction}

The pure fungal isolates were cultured 4-6 days, the micelles were cut using toothpick and transferred to a microtube containing $500 \mu \mathrm{l}$ of lysis buffer. Then incubated at the room temperature of 10 minutes. The blend was centrifuged for 5 minutes at $4^{\circ} \mathrm{C}$ with $18,000 \mathrm{rpm}$. The resulting supernatant was transferred to a sterile microtube and added with $750 \mu \mathrm{l}$ of ethanol then homogenized by turning the tube. The DNA was centrifuged for 2 minute at $4^{\circ} \mathrm{C}$ with $18,000 \mathrm{rpm}$. The results of dried DNA pellets after cleaning with $70 \%$ ethanol were dissolved in $50 \mu \mathrm{TE}$ buffer pH 8.0 (Saitoh et al., 2006).

\section{PCR amplification and sequence of $18 S$ rRNA gene}

The $50 \mu \mathrm{l}$ PCR blend contained $1 \mu \mathrm{l}$ DNA template, 20

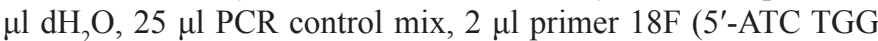
TTG ATC CTG CCA GT-3'), and $2 \mu$ primer 18R (5'-GAT CCT GCA GGT TCA CC-3'). The amplification responses were ruined in a Hybaid Omnigene thermal cycler. An initial denaturation was carried out for 2 minutes at $94^{\circ} \mathrm{C}$ and followed by 30 cycles for 15 seconds at $94^{\circ} \mathrm{C}, 30$ seconds at $60^{\circ} \mathrm{C}$ and 1.30 minutes at $68^{\circ} \mathrm{C}$ and a last prolongation of 10 minutes at $78^{\circ} \mathrm{C}$. The sequences were examined by the BLAST program on NCBI. Phylogenetic tree analysis was assembled by the neighbor-joining method to a bootstrap value of 1,000 replications using MEGA 7.0 software (Kumar et al., 2016).

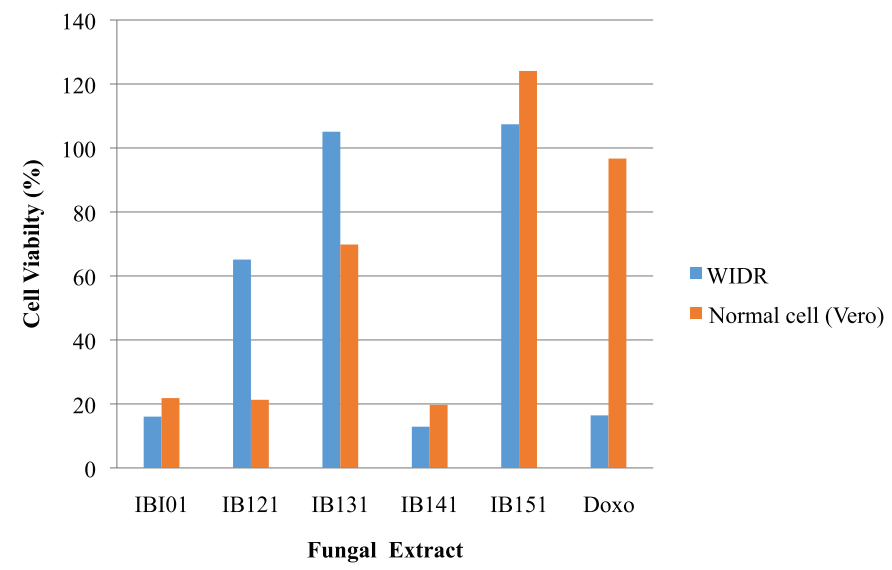

Figure 1. Cytotoxic effect of extract fungi from sponge A. ingens on WiDr and normal cell (Vero) lines. 


\section{RESULTS AND DISCUSSION}

The fungi extracts that showed potential cytotoxity with viability percentage $(\leq 50 \%)$ against the WiDr and Vero cell lines were 1B101, 1B121, and IB141 (Fig. 1). IB141 was the highest cytotoxicity against WiDr cancer compared with Vero normal cells with the percentage of viability $12.88 \%$ and $19.71 \%$, respectively. This IB141 isolate was identified at a molecular level by sequence analysis of the partial $18 \mathrm{~S}$ rRNA gene.

The amplified PCR of the 18S rRNA gene showed that DNA bands were obtained at $978 \mathrm{bp}$. A BLAST search on the NCBI gene deposit showed that this IB141 isolate had a maximum identity of 99\% with Aspergillus ochraceus strain UPSC 1983 (Table 1).

The phylogenetic tree assembled with a neighbor-joining method using a scale bar of 0.5 substitutions per nucleotide. The resulting tree consists of two clades (Fig. 2). Eurotiales (genera Aspergillus) are the dominant group with 24 representatives of the fungus. BLAST and phylogenetic analysis formed on the $18 \mathrm{~S}$ rRNA gene sequences indicate that the IB141 isolate had a 90\% identity with Aspergillus unguis. This is in agreement with the results of the BLAST search.
The IB141 isolate, which can be assumed to be $A$. ochraceus Strain UPSC 1983, was most selective cytotoxic to WiDr cancer and normal Vero cells found in this study.

Based on the results of phytochemical constituents showed that ethyl acetate extract from IB141 isolate contains phenolic and terpenoid compounds (Handayani and Aminah, 2017). In previous studies, alkaloids Stephacidin A and B isolated from $A$. ochraceus WC76466 were found to possess anti-tumor activity (Qian-Cutrone et al., 2002). The fungus $A$. ochraceus JGI25 was also the source of an alkaloid that had notable cytotoxicity against $\mathrm{HeLa}$ cancer cell with the $\mathrm{IC}_{50}$ value being a smaller extent than $40 \mu \mathrm{g} / \mathrm{ml}$ (Nadumane et al., 2013).

Table 1. Molecular identification of IB141 fungi derived isolate from sponge A. ingens based on $18 \mathrm{~S}$ rRNA gene.

\begin{tabular}{ccccc}
\hline Isolate code & Species & $\begin{array}{c}\text { Homology } \\
\mathbf{( \% )}\end{array}$ & Query length & $\begin{array}{c}\text { Access } \\
\text { number }\end{array}$ \\
\hline IB141 & $\begin{array}{c}\text { Aspergillus ochraceus } \\
\text { Strain UPSC 1983 }\end{array}$ & 99 & 978 & LPB_141 \\
\hline
\end{tabular}

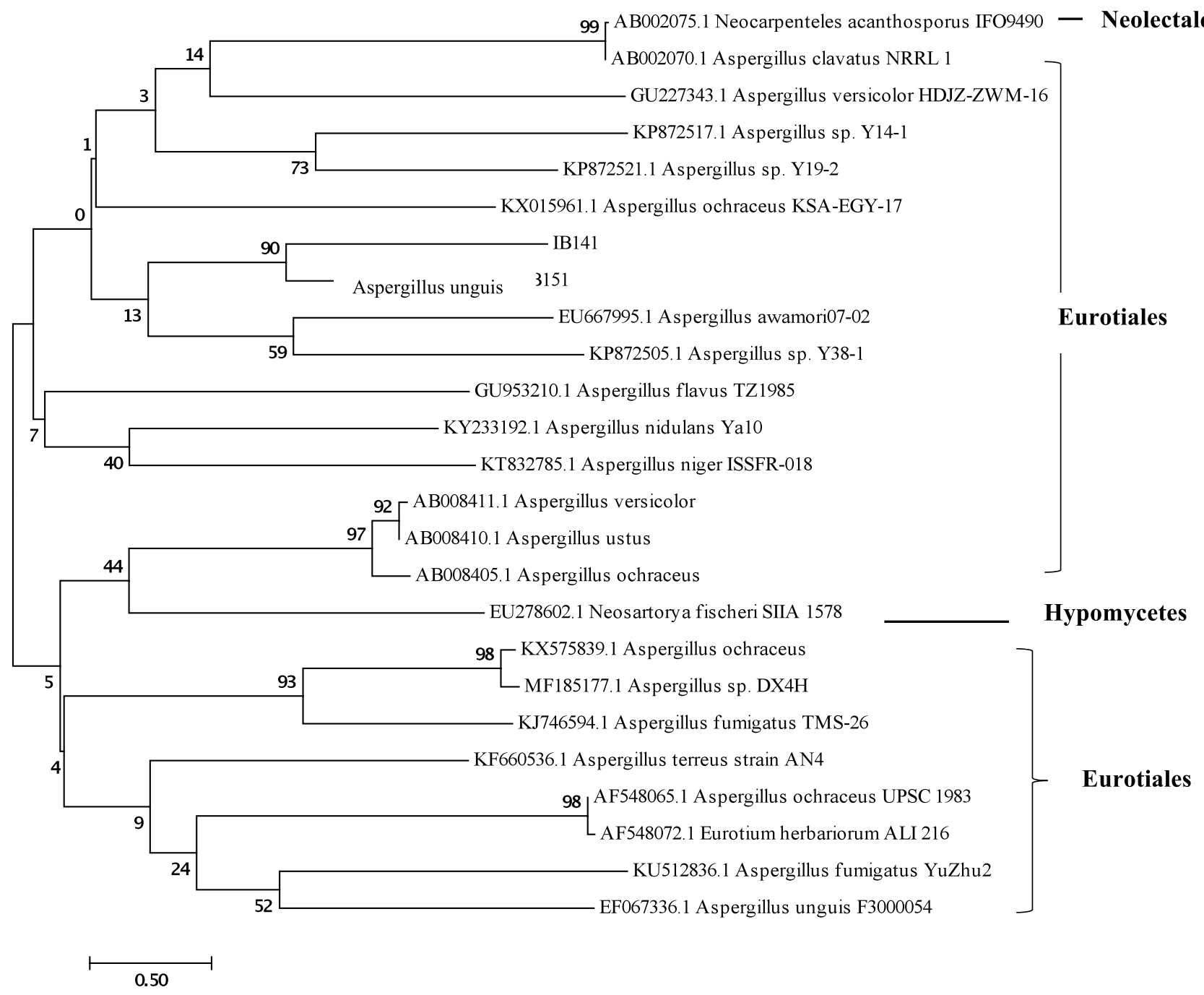

Figure 2. Neighbor-joining phylogenetic tree of marine-derived fungi from sponge A. ingens and some strains of Aspergillus based on $18 \mathrm{~S}$ rRNA gene sequences. The values at each node represent the bootstrap values from 1,000 replicates, and the scale bar represents 0.5 substitutions per nucleotide. 
Identification of novel and new anti-cancer metabolites by using standard screening and isolation methods has proven that fungi from the genus Aspergillus have capability to bring out interesting bioactive compounds (Nadumane et al., 2013). For example, Aspergillus versicolor derived from Petrosia sp. showed some compounds derived from this fungus had $\mathrm{IC}_{50}$ for colon cancer cell of HCT15 lower than $30 \mu \mathrm{g} / \mathrm{ml}$ (Lee et al., 2010). Marine fungus Aspergillus sp. KMD901 contained diketopiperazine disulfide which can induce apoptosis in an HCT116 cancer cells (Chol et al., 2010). Phenylahistin, a diketopiperazine alkaloid was obtained from Aspergillus ustus (Kanoh et al., 1997) and exhibited cytotoxic activity against in vitro tumor A-549, A-431, K-562, HeLa, WiDr, MCF-7, and TE-671 cell lines, with $\mathrm{IC}_{50}$ values ranging from 0.18 to $3.7 \mu \mathrm{M}$ (Kanoh et al., 1999).

In our previous research of anti-cancer-producing compound from marine-derived fungi has been performed, Aspergillus nomius derived of sponge Neopetrosia chaliniformis AR-01 indicated the highest cytotoxic activity against WiDr cell line with percentage of viability of $70.31 \%$ (Artasasta, et al., 2017), and 16 extracts of derived fungi from marine sponge Haliclona fascigera $(80 \%)$ obtained cytotoxicity against HeLa, WiDr, and T47D (Handayani et al., 2017). However, although marine-derived fungi are still had to understudy groups of marine ecological and cognition of regarding the diversity and potential anti-cancer function of fungi derived from the marine sponge $A$. ingens is still very limited. A comparatively high part of positive bio-activity screening results were acquired in this study, applying that fungi derived of the marine sponge $A$. ingens have potential as sources of new anti-cancer compounds.

\section{CONCLUSIONS}

In this study, fungal extract of IB141 derived from marine sponge $A$. ingens was the highest cytotoxicity against WiDr and Vero cell lines. Based on molecular identification result indicated that IB141 was identical to A. ochraceus. The cytotoxicity of this fungus has the potential as an alternative source for new anticancer compounds.

\section{ACKNOWLEDGMENTS}

This study was supported by Directorate General of Higher Education Ministry of Nasional Education (KEMENRISTEK DIKTI), Indonesia, with the project "Master Program of Education Leading to Doctoral Degree for Excellent Graduate (PMDSU) Research, No: 059/SP2H/LT/DRPM/IV/2017." We also thank Dr. Nikole J. De Voogd, Center for Natural Biodiversity, Netherlands for the taxonomic identification of marine sponges.

\section{REFERENCES}

Bhadury P, Mohammad BT, Wright PC. The current status of natural product from marine fungi and their potential as anti-infective agents. J Ind Microbiol Biotechnol, 2006; 33:325-37.

Boopathy NS, Kathiresan K. Anticancer drugs from marine flora: an overview. J Oncol, 2010; 2010:214186.

Bugni TS, Ireland CM. Marine-derived fungi: a chemically and biologically diverse group of microorganisms. Nat Prod Rep, 2004; 21:143-63.

Chol EJ, Park JS, Kim YJ, Jung JH, Lee JK, Kwon HC, Yang HO. Apoptosis-inducing effect of diketopiperazine disulfides produced by Aspergillus sp. KMD 901 isolated from marine sediment on HCT116 colon cancer cell line. J Appl Microbiol, 2010; 110:304-13.
Elsebai MF, Kehraus S, Lindequist U, Sasse F, Shaaban S, Gütschow M, Josten M, Sahle HG, König GM. Antimicrobial phenalenone derivatives from the marine-derived fungus Coniothyrium cereal. Org Biomol Chem, 2011; 9:802-8.

Handayani D, Aminah I. Antibacterial and cytotoxic activities of ethyl acetate extract of symbiotic fungi from West Sumatra marine sponge Acanthostrongylophora ingens. J Appl Pharm Sci, 2017; 7(2):237-40.

Handayani D, Artasasta MA. Antibacterial and cytotoxic activities screening of symbiotic fungi extracts isolated from marine sponge Neopetrosia chaliniformis AR-01. J Appl Pharm Sci, 2017; 7(05):066-9.

Handayani D, Ornando R, Rustini. Antimicrobial activity screening of symbiotic fungi from marine sponge Petrosia nigrans collected from South Coast of West Sumatra Indonesia. Int J Pharmacogn Phytochem Res, 2016; 8(4):623-5.

Handayani D, Rivai H, Hutabarat M, Rasyid R. Antibacterial activity of endophytic fungi isolated from Mangrove plant Sonneratia griffithii Kurz. J Appl Pharm Sci, 2017; 7(04):209-12.

Handayani D, Rivai H, Mulyana R, Suharti N, Rasyid R, Hertiani T. Antimicrobial and cytotoxic activities of endophytic fungi isolated from Mangrove plant Sonneratia alba Sm. J Appl Pharm Sci, 2018; 8(02):049-53

Jadulco R, Brauers G, Edrada RA, Ebel R, Wray V, Proksch P. New metabolites from sponge-derived fungi Curvularia lunata and Cladosporium herbarum. J Nat Prod, 2002; 65(5):730-3.

Jemal A, Bray F, Center MM, Ferlay J, Ward E, Forman D. Global cancer statistics. CA Cancer J Clin, 2011; 66:69-90.

Kanoh K, Konho S, Asari T, Harada T, Katada J, Muramatsu M, Kawashima H, Sekiya H, Uno I. (-)-Phenylahistin: a new mammalian cell cycle inhibitor produced by Aspergillus ustus. Bioorg Med Chem Lett, 1997; 7(22):2847-52.

Kanoh K, Konho S, Katada J, Hayashi Y, Muramatsu M, Uno I. Antitumor activity of phenylahistin in vitro and in vivo. Biosci Biotechnol Biochem, 1999; 63(6):1130-3.

Kjer J, Debbab A, Aly AH, Proksch P. Methods for isolation of marine-derived endophytic fungi and their bioactive secondary products. Nat Protocols, 2010; 5:479-90.

Kumar S, Stecher G, Tamura K. MEGA7: molecular evolutionary genetics analysis version 7.0 for bigger datasets. Mol Biol Evol, 2016; 33(7):1870-4.

Lee DS, Jang JH, Ko W, Kim KS, Sohn JH, Kang MS, Ahn JS, Kim YC, Oh H. PTP1B inhibitory and anti-inflammatory effects of secondary metabolites isolated from the marine-derived fungus Penicillium sp. JF-55. Mar Drugs, 2013; 11:1409-26.

Li YX, Himaya S, Dewapriya P, Zhang C, Kim SK. Fumigaclavine $\mathrm{C}$ from a marine-derived fungus Aspergillus fumigatus induces apoptosis in MCF-7 breast cancer cells. Mar Drugs, 2013; 11:5063-86.

Marmot M, Atinmo T, Byers T, Chen J, Hirohata T, Jackson A, James W, Kolonel L, Kumanyika S, Leitzmann C,Mann J, Powers H, Reddy K, Riboli E, Rivera JA, Schatzkin A, Seidell J, Shuker D, Uauy R, Willett W, Zeisel S. Food, nutrition, physical activity, and the prevention of cancer: a global perspective. World Cancer Research Fund/American Institute for Cancer Research, Washington, DC, 2007.

Nadumane VK, Venkat P, Pal A, Dharod H, Shukla M, Prashanthi K. A novel metabolite from Aspergillus ochraceus JGI 25 showing cytotoxicity to Hela cells. Indian J Pharm Sci, 2013; 75(5):501-14.

Permanasari P, Hertiani T, Yuswanto A. Immunomodulatory effect of Massoia bark extract and the cytotoxicity activity against fibroblast and Vero cells in vitro. Int J Pharma Clin Res, 2016; 8(5) Suppl:326-30.

Pitt JL. A laboratory guide to common Penicillium species. 3rd edition, Food Science, Australia, p. 197, 2000.

Proksch P, Ebel R, Edrada RA, Schupp P, Lin WH, Sudarsono, Wray V, Steube K. Detection of pharmacologically active natural products using ecology, Selected examples from Indopacific marine invertebrates and sponge-derived fungi. Pure Appl Chem, 2003; 75(2):343-52.

Qian-Cutrone J, Huang S, Shu YZ, Vyas D, Fairchild C, Menendez A, Krampitz K, Dalterio R, Klohr SE, Gao Q. Stephacidin A and 
B: two structurally novel, selective inhibitors of the testosterone-dependent prostate LNCaP cells. J Am Chem Soc, 2002; 124(49):14556-7.

Rateb ME, Ebel R. Secondary metabolites of fungi from marine habitats. Nat Prod Rep, 2011; 28:290-344.

Saitoh KI, Togashi K, Arie T, Teaoka T. A simple method for mini-preparation of fungal DNA. J Gen Plant Pathol, 2006; 72:348-50.

Subramani R, Kumar R, Prasad P, Aalbersberg W. Cytotoxic and antibacterial substances against multi-drug resistant pathogens from marine sponge symbiont: Citrinin, a secondary metabolite of Penicillium sp. Asian Pac J Trop Biomed, 2013; 3(4):291-6.

Sun L, Shao CL, Chen JF, Guo ZY, Fu XM, Chen M, Chen YY, Li R, de Voogd NJ, She ZG, Lin YC, Wang CY. New bisabolane sesquiterpenoids from a marine-derived fungus Aspergillus sp. isolated from the sponge Xestospongia testudinaria. Bioorg Med Chem Lett, 2012; 22:1326-9.

Thomas TRA, Kavlekar DP, Lokabharathi PA. Marine drugs from sponge-microbe association - a review. Mar Drugs, 2010; 8:1417-68.

Varga J, Frisvad JC, Samson RA. Two new aflatoxin producing species, and an overview of Aspergillus section Flavi. Studies Mycol, 2011; 69:57-80.
Veer P, Kampman E. Food, nutrition, physical activity and the prevention of cancer: a global perspective. World Cancer Research Fund/ American Institute for Cancer Research, Washington, DC, 2007.

Wiese J, Ohlendorf B, Blumel M, Schmaljohann R, Imhoff JF. Phylogenetic identification of fungi isolated from the marine sponge Tethya aurantium and identification on their secondary metabolites. Mar Drugs, 2011; 9:561-85.

How to cite this article:

Aminah I, Putra AE, Arbain D, Handayani D. Screening of cytotoxic activities using WiDr and Vero cell lines of ethyl acetate extracts of fungi-derived from the marine sponge Acanthostrongylophora ingens. J Appl Pharm Sci, 2019; 9(01):001-005. 